\title{
Segregation, An Alarming Problem that Roma Face in the Education System
}

\author{
Edvin Lame
}

\author{
Doi:10.5901/mjss.2014.v5n27p1385
}

\begin{abstract}
The arrival of the transition period in Albania in 1991 led to a promptly decline in the educational levels which by itself brought a decrease in school attendance and an increase in dropout rates. These patterns are manifested more among the Roma people who face more problems in attending school. The national illiteracy rate found by INSTAT 1 was not more than 2 percent for the Albanian population, but it is as much as 63 percent for Roma girls and 60 percent for Roma boys. It is assumed that it has increased significantly since 19912. It is the equal access to education one of the core problems which the Roma communities in Albania are facing, and it is this deficiency which is also directly related with other problems such as employment and political participation. I believe that in designing new policies and long term solutions for the melioration of the educational situation for Roma community in Albania, it is very important to have a diagnostic situation of the situation of Roma access and equity in education. Hence, the rationale behind this paper is to explore the situation, reasons and respective perspectives for the Roma minority regarding their access and equity in education. The methodology used in this research includes primary and secondary data. The primary data were obtained through semi-structured interviews. Interviews were conducted with one Representative of the Albanian Ministry of Education and Sports and interviews with two teachers of the elementary school "Bajram Curri" Tirana/Albania. Secondary data were obtained for a qualitative character from a range of sources such as reports, documents and studies on the education of Roma in Albania and Central and Eastern Europe.
\end{abstract}

\section{Analysis of the Situation of Roma in Albania}

The Roma group is the biggest ethnic minority living in East Europe and in the Balkan Peninsula. The Roma people live in Albania just like in all Balkan countries ${ }^{3}$.

Roma in Albania are not recognized as an ethnic minority because of the lack of an official kin state, however they are recognized as a linguistic minority by the Albanian constitution. Currently Roma live all over the country, but the biggest communities are concentrated in and around Tirana (the capital city), the towns of Fier, Elbasan, Durres and around the town of Korce. According to different estimates, Roma number is between 8,3004 and 120,000 people out of the total population of 3.4 million in Albania ${ }^{5}$. The huge difference between these two figures reflects in itself the state of affairs of Roma communities in Albania. There are however branded five main Romani tribes in Albania: Meckars, Kabuzis, Kurtofs, Cergars and Bamir6.

Although the Roma enjoyed certain benefits during the communist regime, like employment and the general notion of "security for tomorrow", they were not treated on an equal basis to the majority. That the Roma communities, even in this unnatural homogenization, were considered simply third hand citizens is the same and the only conclusion drawn from many research reports and studies carried out after the fall of communism ${ }^{7}$. However, with the collapse of communism, and the start of economic and political transition to democracy, the Roma were the first to become unemployed and to go rapidly to the bottom of the society. Roma, in line with the general post-communist mentality, feel

\footnotetext{
1 INSTAT- Albanian National Institute of Statistics (2002) Popullsia e Shqiperise ne 2001. Rezultatet Kryesore te regjistrimit te popullsise dhe banesave

2 De Soto H., Beddies S., Gedeshi I., (2005) Roma and Egyptians in Albania, From Social Exclusion to Social Inclusion, World Bank Report No. 53

3 Koinova, M. (2005) Minorities in Southeast Europe, Roma of Albania, Report of Centre for Documentation and Information on Minorities in Europe - Southeast Europe (CEDIME-SE) The Gypsies in Eastern Europe, ME. Sharpe Publisher

4 INSTA (2011) Censusi i Popullsise dhe Banesave

${ }^{5}$ Koinova, M. (2005) Minorities in Southeast Europe, Roma of Albania, Report of Centre for Documentation and Information on Minorities in Europe - Southeast Europe (CEDIME-SE) The Gypsies in Eastern Europe, ME. Sharpe Publisher

${ }^{6}$ Courthiades, M. (1990) A Social and Historical Profile of the Roma in Albania, Part III

${ }^{7}$ Courthiades, M. (1995) Between Conviviality and Antagonism: The Ambiguous Position of Romanies in Albania, Patrin No. 3/1995
} 
nostalgic about their lost security and think that they had enjoyed better life style during communism ${ }^{8}$

The arrival of the transition period in Albania in 1991 led to a promptly decline in the educational levels which by itself brought a decrease in school attendance and an increase in dropout rates ${ }^{9}$. These patterns are manifested more among the Roma people who face more problems in attending school. The national illiteracy rate found by INSTAT in 2001 was not more than 2 percent for the Albanian population, but it is as much as 63 percent for Roma girls and 60 percent for Roma boys. It is assumed that it has increased significantly since $1991^{10}$.

In January 2003 the United Nations Development Programme (UNDP) ${ }^{11}$ released the first comprehensive survey of the Roma minority in five Central and Eastern European countries. The survey, "Avoiding the Dependency Trap", found out that the Roma communities around East Europe Countries seek to integrate socially, economically and politically into their local communities through three main sectors where the first in line was equal access to education, followed by employment opportunities and political participation.

It is the equal access to education one of the core problems which the Roma communities in Albania are facing, and it is this deficiency which is also directly related with other problems such as employment and political participation ${ }^{12}$.

Roma have the right to education in the Albanian municipality schools, but they have no mother-tongue education in those schools. In Albania, these groups rarely face the open discrimination by Albanian politicians or society that is visible in many Eastern European countries. However, they reportedly face more covert, institutional discrimination and social exclusion ${ }^{13}$.

In general the education position of Roma minority is characterised by low performance levels, few transfer to secondary education, drop-outs and low qualifications ${ }^{14}$.

The problems outlined above are certainly typical for Albania, a fact evidenced by studies of local and foreign organizations. It is important to note that the presence of these problems do not necessarily serve as the main reason for the difficulties faced by Roma children in the Albanian education system. It is assumed that most of these problems are the result of two main reasons that will be explained below.

Essential reasons thought to affect not only in Albania but also in other European countries are: a) the education system itself as biased and exclusionary instrument and b) the conflict between traditional Roma education and mainstream education.

\subsection{The Education system itself as biased and exclusionary instrument}

Segregation and exclusion is what constitutes the Europe Roma pupils experience even within the schools. The segregation is not said openly as an ethnic one but it is supported and justified by several pedagogical, linguistic or social reasons. The school environment doesn't help to change the fixed ideas that all society has for Roma children, so they are continually stigmatized and treated in a way that makes them feel unimportant ${ }^{15}$.

Given the patterns of segregation and the historical and political invisibility of this minority, different researchers, educators and policymakers have originated many explanations in an attempt to interpret and recognize its disaffection for schooling. One of the theories explains Roma disaffection for schooling is the ethnocentric theory. As part of larger philosophical tradition this theory has brought a series of viewpoints and suppositions that delineate the "other" and "its" state. There are viewpoints and suppositions, veiled under these traditions of ethnocentrism, which propagate the patterns of segregation and exclusion in educational research, policy, and practice in Europe ${ }^{16}$.

\footnotetext{
${ }^{8}$ Koinova, M. (2005) Minorities in Southeast Europe, Roma of Albania, Report of Centre for Documentation and Information on Minorities in Europe - Southeast Europe (CEDIME-SE) The Gypsies in Eastern Europe, ME. Sharpe Publisher

${ }^{9}$ De Soto H., Gordon P., Gedeshi l., Sinoimeri Z., (2002) Poverty in Albanai: A Qualitative Assessment, Technical Paper No. 520, Washington DC: The World Bank

${ }^{10}$ De Soto H., Beddies S., Gedeshi I., (2005) Roma and Egyptians in Albania, From Social Exclusion to Social Inclusion, World Bank Report No. 53

11 UNDP- United Nations Development Programme, RCS Staff Report (2003) Avoiding the Dependency Trap.

${ }^{12}$ De Soto H., Beddies S., Gedeshi I., (2005) Roma and Egyptians in Albania, From Social Exclusion to Social Inclusion, World Bank Report No. 53

${ }^{13}$ Koinova, M. (2005) Minorities in Southeast Europe, Roma of Albania, Report of Centre for Documentation and Information on Minorities in Europe - Southeast Europe (CEDIME-SE) The Gypsies in Eastern Europe, ME. Sharpe Publisher

${ }^{14}$ Ringold, D. (2000) Roma and the transition in Central and Eastern Europe: Trends and challenges, World Bank

${ }^{15}$ ERRC- European Roma Right Centre (2004) Stigmata: Segregated schooling of Roma in Central and Eastern Europe, Budapest

${ }^{16}$ Claveria, J.V. \& Alonso, J.G. (2003) Why Roma do not Like Mainstream schools: Voice of People without Territory, in Harvard Educational Review, Vol. 73, Nr.4, pg. 559-590
} 
Ethnocentrism is described as the postulation that the other races are inferior to the European race, and the position of the Western culture is seen as the best model that the other societies should accept in order to improve ${ }^{17}$. To have a different way of being and doing things is considered dangerous for the world's unity and stability. Under this tradition, as Amartya Sen argues ${ }^{18}$, "The world is invited to join the club of 'Western democracy' and to admire and endorse traditional 'Western values'" (p. 233) which are considered the true and the right values for every other culture and society. Based on the ethnocentric perspective, the Roma, in order to succeed in education, need to adapt to the European Western patterns, leave aside their culture and traditional values and become members of the mainstream culture. A not satisfying attitude towards school of Roma is seen as a lack of habituation with universal values of learning.

All the States try to minimize or better to wipe out the differences of Roma people in their educational policies. These differences bring about problems in Roma people education.

The truth about the European education systems in relation with the Roma people is that these systems are not only helping to change the marginalization of the Roma people but they are also contributing to stereotypes, prejudices and social exclusion, making it possible that discrimination against Roma people will continue to exist and last for a long time 19

Actually besides family, school is one of the basic places where children learn about culture, attitudes and public life in general. Social exclusion is another thing they learn from education practices and this is the critical part of it. Research conducted recently has found many factors that contribute to social exclusion both inside and outside education. These studies see a close connection between them; they both strengthen each other but in different ways and in different stages in life ${ }^{20}$.

Education is seen worldwide as a decisive factor to deal with social exclusion. In the past, European schools dealt with a homogenous student body and aimed at giving them a homogenous Western white culture, but nowadays the student body has become heterogeneous even though the educational systems have not been diversified, causing in this way a tension and a need for diversification. Furthermore, the old teaching programs are not adaptable to the diversified classrooms; they lack the knowledge and the special training. The only thing left to be done by the ethnic groups is to adapt to European white society in order to be successful in education. If they do not, they will always have problems with their education ${ }^{21}$.

Public education still remains a decisive issue of dealing with minorities in Central and Eastern Europe. The equal access to education still constitutes a challenge for Roma people in Albania. Roma parents have underlined the fact that their children have been abused by other children and by teachers. According to Mrs. Edlira Durici22, discrimination against the Roma children does exist in Albanian schools, albeit not as racial discrimination per se. She confirmed that "Teachers do not discriminate Roma children because they are Roma but because of their poor performance. Actions like making them sit in the last rows of the classroom, are used as punishment for all children who perform poorly". From her point of view since the Roma children constitute the majority of poorly-performing pupils; this happens more often to them. She also claimed "This form of punishment is often encountered in schools where there are Roma children and is known as "silent abandonment".

Furthermore Roma families are used to scenes where non-Roma children and teacher come together to oppose their acceptance in school ${ }^{23}$, or when schools don't accept Roma children justified by the low ${ }^{24}$.

From the interview with a teacher of elementary school "Bajram Curri" Tirana/Albania25, I realised that there are three elementary schools near this neighbourhood and although Roma children have the right to enrol in these schools, this right has been denied to them in two of the schools. The teacher underlined the fact that "the authorities of the schools "Gjon Buzuku" and "Ramazan Jarani" don't permit the Roma children to be enrolled because of their race.

\footnotetext{
${ }_{17}$ Mills, G. W. (1997) The racial contract, Ithaca NY: Cornell University Press

18 Sen, A. (1999). Development as Freedom, New York: Anchor Books

${ }^{19}$ Claveria, J.V. \& Alonso, J.G. (2003) Why Roma do not Like Mainstream schools: Voice of People without Territory, in Harvard Educational Review, Vol. 73, Nr.4, pg. 559-590

20 Claveria, J.V. \& Alonso, J.G. (2003) Why Roma do not Like Mainstream schools: Voice of People without Territory, in Harvard Educational Review, Vol. 73, Nr.4, pg. 559-590

${ }^{21}$ Flecha, R. (1999) Modern and Post modern Racism in Europe: Dialogic Approach and anti-racist pedagogies, Harvard Educational review, Nr. 69, pg. 150-171

22 Semi-structure interview with the Representative of Ministry of Education and Sports of Albania : Mrs. Edlira Durici, 12/09/2014

${ }_{23}$ ERRC- European Roma Right Centre (2004) Stigmata: Segregated schooling of Roma in Central and Eastern Europe, Budapest

${ }^{24}$ Cahn, C., Chiricho, D., Mc Donald C., Mohacsi V., Pric T., Szkely A., Roma in the educational system of Central and Eastern Europe, in The Roma Resource Book (1999) Open Society Institute-Institute for Educational Policy, Budapest

25 Semi-structure interview with the teacher of elementary school 'Bajram Curri” Tirana/Albania: Mr. Jashik Zonja, 15/09/2014
} 
Consequently, the number of Roma pupils in the "Bajram Curri" school is high, because in this school they face no difficulties enrolling".

The representative of Albanian Ministry of Education ${ }^{26}$ confirmed that this was a common occurrence in many elementary schools. She said "this was happening not because of discrimination against their race but due to their poor performance in school the authorities of these schools have prejudged the Roma children by not enrolling them and choosing, instead, other children whom they expect to perform better".

Teachers' beliefs that the Roma don't like school influence the way they behave and think towards them. These beliefs are based on the statistically proven patterns of low attendance and high dropout rates which affect how Roma students performance ${ }^{27}$.

The World Bank research has given an analysis for Roma children schooling which shows that in Albania the educational system has difficulties in dealing with Roma children positively. The cause of this is the increasing number of Roma children who fail to achieve results in school and as a result they drop outs even though the elementary school program is obligatory in the Albanian school system ${ }^{28}$.

\subsection{The Conflicts between Traditional Roma Education and Mainstream Education}

Many studies conducted all over the world and Roma families themselves refer to the family as the most important influence in a Roma child's life. However, nowadays the dominant society through its culture, the school and media, plays its own role in their understanding of the world.

The Roma community encourages the children to be independent by learning and reinforcing behaviours such as to prepare food and be dressed by themselves, or to go to bed without any supervision and care ${ }^{29}$. Even though Roma children have less social responsibilities than the others they take some economic responsibilities such as child-care or small jobs which often are imitations of the economic activities of the adults in community.

They face difficulties in interacting and playing with other children in the classroom due to the fact that from an early age they have stayed with adults and have learned working skills because they help their families in many economic activities like flower selling, scrap metal collecting, fortune telling etc. The positive effect of staying with adults in the community is that children learn to read and understand verbal and nonverbal communication skills such as language, hand signals, facial expressions, whistling signals etc. Roma children speak the Roma language which they have by tradition learned without instructions, just through contact ${ }^{30}$.

Children learn the communication skills of story-telling just by listening, observing and involving and by 10 to12 years of age they can tell stories, use jokes and surprising endings just like them. This shows the positive role that verbal communication skills bring into the Roma societies ${ }^{31}$. Mrs. Drita Kolndreu ${ }^{32}$ claimed that the Roma poor performance in school is related to the way they obtain the information on the history, tradition and the world outside in their community. She said "They have learnt Roma language and the Roma history from the legends and songs of the elders of the community, so they have learnt everything as a group". Furthermore she claimed that "Roma children find it difficult to obtain information from the school teachers, who are not members of the Roma community, thus they often cannot get accustomed to this way of learning and thereby perform poorly at school".

Roma traditional education is different in many ways from the mainstream education. The Roma children most of the time stay with their family and other members of the Gypsy community and so they have little or no interaction with non-gypsy people. The classroom is completely a different environment from the Roma community; Roma children are taught by a teacher who is not a family member and they are surrounded by no-Roma children. The classrooms are closed environments where children must stay seated and respect the rules of behaviour, things that Roma children are

${ }^{26}$ Semi-structure interview with the Representative of Education Ministry of Albania : Mrs. Edlira Durici, 12/09/2014

${ }^{27}$ Cahn, C., Chiricho, D., Mc Donald C., Mohacsi V., Pric T., Szkely A., Roma in the educational system of Central and Eastern Europe, in The Roma Resource Book (1999) Open Society Institute-Institute for Educational Policy, Budapest

${ }^{28}$ De Soto H., Beddies S., Gedeshi I., (2005) Roma and Egyptians in Albania, From Social Exclusion to Social Inclusion, World Bank Report No. 53

${ }^{29}$ Berthier, J.C. (1997) The socialization of the gipsy child, International Social Science, Journal, 4, pg. 3

30 Smith, T. (1997) Recognising Differences: The Romani "Gypsy" child socialization and education process, British Journal of Sociology of Education, June 1997, Vol. 18 Issue 2, p243, 14p.

${ }^{31}$ Smith, T. (1997) Recognising Differences: The Romani "Gypsy" child socialization and education process, British Journal of Sociology of Education, June 1997, Vol. 18 Issue 2, p243, 14p.

32 Semi-structure interview with the teacher of elementary school "Bajram Curri" Albania Albania : Mrs. Drita Kolndreu 22/09/2014 
not used to at all33.

A Roma child lacks the ability to stay quiet, have discipline and learn abstract things. Teachers don't understand them and their way of living which is different from the other children. This brings disagreements and discourages them to go to school 34 .

"According to the representative of the Albanian Ministry of Education there are many difficulties when teaching Roma children because of their different tradition and culture. There are no programmes aiming to inform them on the Roma tradition, culture and history that have been organised by the Ministry of Education. The teacher Jashik Zonja ${ }^{35}$ has confirmed that he tried to get more information in this regard by attending some courses organised from different non-governmental organisations"

They also face difficulties in school because the way knowledge is used is different from Roma and mainstream education. In Roma society decisions are made with the agreement of all the community. Contrary to that, the Western societies function through large-scale bureaucracies which make the decisions. The use of time in Western societies is future-oriented in contrast to the Roma society, where as Yoors ${ }^{36}$ says, it is without "apparent goal outside of plain survival and self-perpetuation" and without the security associated with routine.

The Roma society takes the knowledge orally from the elderly who have life experience and remember traditional customs, whereas knowledge in Western societies is a collection of ideas and data which are written and studied ${ }^{37}$.

The most remarkable difference between Roma and mainstream education is the content of the learning systems. A Roma child who stays most of the time in community learns about its culture, history, social and economic life in order to be prepared for his role in the Roma society, whereas at school he learns about the mainstream culture and history. Therefore it is improbable for a Roma child in a mainstream classroom to learn the skills and develop the sense of independence that his role in the community needs ${ }^{38}$.

\section{Conclusion and Recommendation}

This paper tries to emphasise that segregation and exclusion are what the Roma children experience even within the schools. The segregation is supported and justified by the Roma's low performance in schools and quantity of drop outs. Albanian teachers' belief that the Roma do not like the schooling process and the influence it has on pupils, this is largely due to their conduct towards them and general way of thinking. The unwillingness to alter school environment does not contribute to change Albanian society's fixed mentality regarding Roma children, as a consequence they are continued to be stigmatized.

Nowadays, the student body in the school close to the areas were Roma people live has become heterogeneous even though the educational system has not been diversified, causing a tension and a need for diversification.

Although the Albanian government has developed policies for the Roma education the research reflects that these policies should also include steps for impeding the segregation and exclusion of Roma in the Albanian educational system because of their ethnic background.

\section{Principles of the Roma Education Policy}

The national policy on Roma education should also include more rights-based steps of desegregation like:

-Free choice: The Ministry of Education has issued a directive which allows Roma children to enrol in school without the necessary documents, just by going to the schools accompanied by their parents. Despite this directive, the Roma parents face other difficulties for choosing a school for their children. This Ministry should find the ways to eliminate all the other barriers that don't allow the Roma parents to have free choice.

${ }^{33}$ Smith, T. (1997) Recognising Differences: The Romani "Gypsy" child socialization and education process, British Journal of Sociology of Education, June 1997, Vol. 18 Issue 2, p243, 14p.

${ }^{34}$ Lenner, K. (1993) Paper 5, Federal Republic of Germany: in The Education of Gipsy and Traveler children. Action research and coordination, English translation, United Kingdom, University of Hertfordshire Press, pg. 57-59

${ }^{35}$ Semi-structure interview with the teacher of elementary school 'Bajram Curri” Tirana/Albania: Ms. Jashik Zonja, 15/09/2014

${ }_{36}$ Yoors, J. (1997) The Gypsies, New York, Simon and Shuster

${ }^{37}$ Keeffe, K. (1992) From Centre to the City. Aboriginal education, culture and power, Canberra, Australia, Aboriginal Studies Press

${ }^{38}$ Smith, T. (1997) Recognising Differences: The Romani "Gypsy" child socialization and education process, British Journal of Sociology of Education, June 1997, Vol. 18 Issue 2, p243, 14p. 


\section{Prevention of Segregation of Roma Children}

In order to prevent additional segregation in schools, the Ministry of Education must organise obligatory pre-school programs. These programs must go on from 10 to 12 months and they must prepare the children for the mainstream education. These programs have to prevent linguistic barriers and also barriers occurring from the social deprivation of impoverished. These programs ought to assure that the Roma children will be sufficiently prepared for school. They have to be organised and integrated into school institutions and all the other segregated places, where these programs may be organised have to be eradicated and forbidden.

\section{General Measures to Ensure Successful Desegregation Policies on Roma}

\section{Curriculum Reform}

1) The school curriculum requires changing, enabling all pupils to gain basic knowledge regarding Roma and their contribution to society.

2) Apply programmes which support revere for cultural variety in the schools.

3) The Albanian Government needs to effectively counter prejudice and hostility against Roma by implementing anti-bias training programmes on a national scale, which should also be introduced on the teaching degrees.

Awareness Rising

In this policy steps should be taken to end the cruel treatment of Roma children at school, even though Roma children represent lower school performance. Measures have to be taken for prohibiting the teachers in using forms of punishments against Roma children like placing them to the last rows and also forcing them to stand with one foot in front of the classrooms, picketing their ear or even beating them.

Monitoring

The Albanian Ministry of Education should create a body of experts were have to be involved also Roma representatives. They have to supervise the implementation of desegregation action and also to contact Roma parents for gathering complains regarding segregation.

\section{References}

Berthier, J.C. (1997) The socialization of the gipsy child, International Social Science, Journal, 4, pg. 3

Claveria, J.V. \& Alonso, J.G. (2003) Why Roma do not Like Mainstream schools: Voice of People without Territory, in Harvard Educational Review, Vol. 73, Nr.4, pg. 559-590

Courthiades, M. (1990) A Social and Historical Profile of the Roma in Albania, Part III

Courthiades, M. (1995) Between Conviviality and Antagonism: The Ambiguous Position of Romanies in Albania, Patrin No. 3/1995

De Soto H., Beddies S., Gedeshi I., (2005) Roma and Egyptians in Albania, From Social Exclusion to Social Inclusion, World Bank Report No. 53

De Soto H., Gordon P., Gedeshi I., Sinoimeri Z., (2002) Poverty in Albanai: A Qualitative Assessment, Technical Paper No. 520, Washington DC: The World Bank

ERRC- European Roma Right Centre (1997) No record of the case: Roma in Albania, Country Report Series No.5, June

ERRC- European Roma Right Centre (2004) Stigmata: Segregated schooling of Roma in Central and Eastern Europe, Budapest

Flecha, R. (1999) Modern and Post modern Racism in Europe: Dialogic Approach and anti-racist pedagogies, Harvard Educational review, Nr. 69, pg. 150-171

Lenner, K. (1993) Paper 5, Federal Republic of Germany: in The Education of Gipsy and Traveler children. Action research and co-ordination, English translation, United Kingdom, University of Hertfordshire Press, pg. 57-59

INSTAT- Albanian National Institute Of Statistics, (2002) Popullsia e Shqiperise ne 2001. Rezultatet Kryesore te regjistrimit te popullsise dhe banesave

Keeffe, K. (1992) From Centre to the City. Aboriginal education, culture and power, Canberra, Australia, Aboriginal Studies Press

Koinova, M. (2005) Minorities in Southeast Europe, Roma of Albania, Report of Centre for Documentation and Information on Minorities in Europe - Southeast Europe (CEDIME-SE) The Gypsies in Eastern Europe, ME. Sharpe Publisher

Mills, G. W. (1997) The racial contract, Ithaca NY: Cornell University Press

Ringold, D. (2000) Roma and the transition in Central and Eastern Europe: Trends and challenges, World Bank Report

Yoors, J. (1997) The Gypsies, New York, Simon and Shuster

Sen, A. (1999). Development as Freedom, New York: Anchor Books

Smith, T. (1997) Recognising Differences: The Romani "Gypsy" child socialization and education process, British Journal of Sociology of Education, June 1997, Vol. 18 Issue 2, p243, 14p.

UNDP- United Nations Development Programme, RCS Staff Report (2003) Avoiding the Dependency Trap.

Semi-structure interview with the teacher of elementary school "Bajram Curri" Tirana/Albania Albania : Mrs. Drita Kolndreu, 22/09/2014

Semi-structure interview with the Representative of Education Ministry of Albania: Mrs. Edlira Durici, 12/09/2014

Semi-structure interview with the teacher of elementary school 'Bajram Curri” Tirana/Albania: Mr. Jashik Zonja, 15/09/2014 